\title{
HISTOLOGICAL AND HISTOCHEMICAL CHARACTERIZATION OF THE SECRETORY CELLS OF Choeradoplana iheringi GRAFF, 1899 (PLATYHELMINTHES: TRICLADIDA: TERRICOLA)
}

\author{
SOUZA, S. A. de and LEAL-ZANCHET, A. M. \\ Instituto de Pesquisas de Planárias, Centro de Ciências da Saúde, Universidade do Vale do Rio dos Sinos, \\ CEP 93022-000, São Leopoldo, RS, Brazil \\ Correspondence to: Ana Maria Leal-Zanchet, Instituto de Pesquisas de Planárias, \\ Centro de Ciências da Saúde, Universidade do Vale do Rio dos Sinos, CEP 93022-000, \\ São Leopoldo, RS, Brazil, e-mail: ipp@cirrus.unisinos.br \\ Received October 25, 2002 - Accepted April 16, 2003 - Distributed May 31, 2004
}

(With 14 figures)

\begin{abstract}
The present study aims at providing a detailed description of the histology, as well as the first histochemical characterization, of the secretory cells of the epidermis, pharynx, and copulatory organs of Choeradoplana iheringi, in order to give further support to studies on the physiology of these organs. The secretory cells are distinguished on the basis of secretion morphology and its staining properties, using trichrome methods and histochemical reactions. Four cell types open through the epidermis of $C h$. iheringi, three of them secreting basic protein and a fourth containing glycosaminoglycan mucins. The epidermal lining cells store glycogen. In the pharynx, four secretory cell types were distinguished. Two types produce glycoprotein, a third type secretes basic protein, and another one produces glycosaminoglycan mucins. In the male copulatory organs, the prostatic vesicle receives four secretory cell types containing basic protein, except for one type which produces glycoprotein. The two secretory cell types opening into the male atrium secrete, respectively, glycoprotein, and glycosaminoglycan mucins. In the female copulatory organs, the female atrium and its proximal diverticulum, the vagina, receive two types of secretory cells producing, respectively, basic protein and glycosaminoglycan mucins. Another secretory cell type constitutes the so-called shell glands which open into the common glandular duct, secreting basic protein. The lining cells of the male and female atria produce a mucous secretion containing glycosaminoglycans. In addition, the lining epithelium of the female atrium presents an apical secretion of a proteic nature. The occurrence of a kind of spermatophore is reported for the first time for a species of Choeradoplana. This structure is located in the male or female atria in different specimens, and characterized by erythrophil, xanthophil, and/or mixed secretions associated with sperm.
\end{abstract}

Key words: epidermal glands, pharyngeal glands, copulatory organs, sperm transfer, spermatophore.

\section{RESUMO}

\section{Caracterização histológica e histoquímica das células secretoras de Choeradoplana iheringi Graff, 1899 (Platyhelminthes: Tricladida: Terricola)}

O presente estudo tem por objetivo fornecer detalhada descrição da histologia e a primeira caracterização histoquímica das células secretoras da epiderme, da faringe e do aparelho reprodutor de Ch. iheringi, visando a propor estudos da fisiologia desses órgãos. As células secretoras foram diferenciadas com base na morfologia da secreção e em sua coloração, com métodos tricrômicos e reações histoquímicas. Quatro tipos de células secretoras desembocam na epiderme de Ch. iheringi, sendo três com secreção protéica básica e uma do tipo mucoso, contendo glicosaminoglicanas. As células de revestimento que compõem a epiderme armazenam glicogênio. Na faringe, quatro tipos de células secretoras são observadas: 
duas produzem secreção de natureza glicoprotéica, uma apresenta secreção protéica básica e uma secreta glicosaminoglicanas. No aparelho copulador masculino, em sua vesícula prostática desembocam quatro tipos de células secretoras, as quais contêm secreção protéica básica, excetuando uma cuja secreção é de natureza glicoprotéica. O átrio masculino recebe a desembocadura de dois tipos de células secretoras, um tipo contendo secreção glicoprotéica e outro, glicosaminoglicanas. No aparelho copulador feminino, o átrio feminino e seu divertículo ental, a vagina, recebem a desembocadura de dois tipos de células secretoras, que produzem, respectivamente, proteína básica e glicosaminoglicanas. Um outro tipo de célula secretora constitui as chamadas glândulas da casca, que desembocam no ducto glandular comum e secretam proteína básica. As células de revestimento dos átrios masculino e feminino produzem secreções mucosas constituídas por glicosaminoglicanas. O epitélio de revestimento do átrio feminino apresenta, ainda, um tipo diferenciado de secreção protéica acumulada apicalmente. A ocorrência de um tipo de espermatóforo é registrada pela primeira vez para uma espécie de Choeradoplana. Tal estrutura foi observada em três espécimes, ocorrendo no átrio masculino ou feminino, sendo caracterizada pela associação de espermatozóides com secreções eritrófilas, xantófilas e/ou mistas.

Palavras-chave: glândulas epidérmicas, glândulas faringeais, órgãos copuladores, transferência de espermatozóides, espermatóforo.

\section{INTRODUCTION}

The taxonomic determination of land planarians is done by combinations of characters of external and internal morphology. The microanatomy and histology of the pharynx and reproductive organs, as well as of the epidermis and the cutaneous and mesenchymatic musculature, provide taxonomic characters for Terricola. A reliable interpretation of characters depends on an understanding of the functional anatomy of organ systems (Winsor, 1998). In spite of the importance of detailed histological and histochemical studies for a correct interpretation of organ physiology, such studies are very scarce for land planarians, the studies done by Winsor (1990, 1998) being very important because of the numerous histochemical methods, as well as their combination with electronmicroscopical studies.

Neotropical land planarians have been the subject of histological studies in order to determine and describe taxa (Bois-Reymond Marcus, 1951; Marcus, 1951; E.M. Froehlich, 1955, 1978; C.G. Froehlich, 1955, 1956, 1959; Carbayo \& LealZanchet, 2001; Leal-Zanchet \& Carbayo, 2001; among others), but detailed histological and histochemical studies have as yet not been done.

The present study aims at providing a detailed histological study and the first histochemical characterization of the secretory cells of the epidermis, pharynx, and copulatory organs of Choeradoplana iheringi, in order to support further studies on the physiology of these organs.

\section{MATERIAL AND METHODS}

Mature specimens of Choeradoplana iheringi Graff, 1899 measuring approx. $50 \mathrm{~mm}$ in length, were collected in the National Forest of São Francisco de Paula, Rio Grande do Sul, Brazil, and fixed in Lillie's 10\% neutral formalin (Romeis, 1989), dehydrated in an ascending ethanol series, treated with isopropanol, and embedded in Paraplast (Hauser, 1952). Serial sagittal sections ( $6 \mu \mathrm{m}$ thick) were stained with Heidenhain's AZAN, Goldner's Masson, or Cason's Mallory and submitted to the following histochemical reactions: Alcian Blue-Periodic Acid Schiff (AB/PAS) (Pearse, 1968), Best's Carmine (Romeis, 1989), Bonhag's bromophenol blue (AB/PAS) (Pearse, 1968), Adams's DMAB (Romeis, 1989), and Yasuma \& Itchikawa's Ninhydrin (Romeis, 1989). PAS-diastase was used as a control for glycogen.

Additional material was fixed in a variation of Karnovsky's fixative solution of $4 \%$ paraformaldehyde in $0.05 \mathrm{~m}$ phosphate buffer and $4 \%$ aqueous glutaraldehyde, pH 7.2 (Plattnert, 1975), washed in Sörensen's phosphate buffer (Ruthmann, 1966), dehydrated in ethanol, and embedded in HISTORESIN (Reichert-Jung). Transversal and sagittal $3 \mu \mathrm{m}$ thick sections were stained with toluidine blue (Spurlock et al., 1966).

Cell bodies and secretory granules were measured using a calibrated eyepiece micrometer. The sections were analysed and photographed with a Zeiss Axioskop microscope. Color descriptors, based on uptake of dyes of particular colors, were used for 
classification of secretions with trichrome methods: erythrophil (red-loving), xanthophil (orange-loving), and cyanophil (dark blue-loving). The term cyanophil also applies to secretions which have an affinity for the green dye of Goldner's Masson.

\section{RESULTS}

Epidermis (Figs. 1-3, Table 1). Four cell types open through the epidermis of Choeradoplana iheringi at the level of the pre-pharyngeal region, one type being cyanophil (type e1) and the other types erythrophil or xanthophil (types e2, e3 and e4). The cell bodies of these secretory cells are located in the mesenchyme, under the longitudinal cutaneous muscles.

Type e1 cells open through the dorsal and ventral epidermis, being more abundant throughout the creeping sole. In paraplast sections their cytoplasm shows an amorphous cyanophil secretion, which appears in HISTORESIN sections as very fine secretory granules (Fig. 1). The secretion is moderately positive to $\mathrm{AB}$ and metachromatic with toluidine blue, indicating that it is composed of glycosaminoglycans.

The openings of type e 2 cells (Fig. 2) are abundant throughout the creeping sole and at the body margins. Their cell bodies are filled with fine xanthophil secretory granules which stain slightly positively to bromophenol blue, thus indicating a basic proteinaceous nature.

Secretory cells of type e 3 and e 4 correspond to the rhabidthogen cells, both containing secretory granules, the rhabidtes, of the adenal type. Type e3 cells (Fig. 3) open through the dorsal epidermis and throughout the body margins, being very abundant. Their rhabidtes are very thin and extremely long; their length is frequently greater than the epidermis thickness, causing them to form a spiral. Type e4 cells (Fig. 2) open throughout the creeping sole, presenting a scattered distribution. They contain thicker and shorter rhabdites, being often concentrated in the basal or apical region of the epidermis. The xanthophil secretion of both types is strongly positive to bromophenol blue and moderately positive to Ponceau $2 \mathrm{R}$, being constituted of basic protein.

The basal cytoplasm of the epidermal lining cells shows glycogen granules (approx. $1 \mu \mathrm{m}$ in diameter) detected by their strong positive reaction to Best's carmin.

Pharynx (Figs. 4-5, Table 2). The four secretory cell types of the pharynx of Ch. iheringi show cell bodies situated in the mesenchyme of the pre- or post-pharyngeal region (Fig. 4), mainly between intestinal branches, with long cell necks traversing the pharynx to open on all the pharyngeal surface (Fig. 5).

Secretory cells of type ph1 (Fig. 4) show fine secretory granules, which fill the cell body, so that the spherical nucleus occupies a marginal position. Their xanthophil secretion stains moderately positive to bromophenol blue and Ponceau 2R, thus indicating a basic protein type.

Type ph 2 cells present a cell body with cyanophil cytoplasm and few secretory granules. The spherical and central nucleus shows a prominent nucleolus. The xanthophil secretory granules stain moderately to strongly positive to bromophenol blue, Ponceau 2R, DMAB, and PAS, indicating a glycoproteic type of secretion containing tryptophane.

Type ph3 cells show a small cell body with central nucleus and few secretory granules. Their fine erythrophil secretory granules are surrounded by a cyanophil cytoplasm, being moderately positive to PAS and DMAB, this indicating glycoprotein containing tryptophane.

Secretory cells of types ph4 are mucocytes, presenting a cyanophil amorphous secretion which fills the cell body, so that the spherical nucleus occupies a marginal position (Fig. 4). Their secretion is moderately positive to $\mathrm{AB}$, thus indicating glycosaminoglycans.

Male copulatory organs (Figs. 6-9, Table 3). The prostatic vesicle of $C h$. iheringi shows two portions, a tubular proximal and a globous distal region. The cell types which open into this organ show cell bodies located in the mesenchyme surrounding the proximal part of the copulatory apparatus, externally to the common muscle coat. Four cell types (pv1, pv2, pv3, and pv4) open through the epithelium of the prostatic vesicle. Type pv1 (Fig. 6) occurs in the proximal part, whereas types pv3 and pv4 are present exclusively in the distal portion. Type pv2 (Fig. 7) shows a scattered distribution, but occurs in all the prostatic vesicle. Type pv3 cells (Fig. 8) are the most frequent throughout the distal portion. Type pv4 cells (Fig. 8) differ from all other secretory cell types in that they contain granules with a mixed secretion, i.e., presenting a cyanophil marginal zone and a xanthophil/ erythrophil central core, which show a glycoproteic type of secretion according to the histochemical reactions. Types pv1, pv2, and pv3 show different reactions to the trichrome staining 
methods and a positive/negative reaction to $\mathrm{DMAB}$, this indicating different types of proteinaceous secretion. Tryptophane was detected in the secretion of pv1, pv2, and pv4 cells.

The male atrium receives the openings of two types of secretory cells (Fig. 9). Type mal cells show cell bodies situated in the mesenchyme surrounding the male copulatory apparatus, externally to the muscle coat, and long cell necks which open throughout the male atrial epithelium. Their fine erythrophil/ xanthophil secretory granules contain a glycoproteic type of secretion, which stains moderately to strongly positive to bromophenol blue, Ponceau 2R, Ninhydrin, and PAS. It also stains positively to DMAB, thus indicating that the secretion contains tryptophane. The secretory cells of type ma2 present a subepithelially located cell body and an amorphous cyanophil secretion. It stains moderately positive to $\mathrm{AB}$, indicating glycosaminoglycans.

The lining cells of the male atrium show cytoplasm filled with a cyanophil secretion which stains slightly positively to $\mathrm{AB}$, indicative of glycosaminoglycans.

Female copulatory organs (Figs. 10-13, Table 4). The shell glands, which open through the common glandular oviduct and the distal part of the oviducts, show abundant erythrophil/xanthophil secretory granules. Their cell bodies are located in the mesenchyme posteriorly to the copulatory apparatus. Their secretion indicates a glycoproteic nature, which stains strongly positively to bromophenol blue (Fig. 10) and PAS.

The female atrium and its proximal diverticulum, the vagina, receive two types of secretory cells (Figs. 11, 12), the cell bodies of which are subepithelially located. Type fa1 and val cells exhibit fine erythrophil or xanthophil secretory granules which stain moderately positively to Ninhydrin and bromophenol blue, indicating a basic protein type of secretion. Type fa2 and va2 cells show, similarly to ma2 cells, an amorphous secretion which stains positively to $\mathrm{AB}$, thus indicating glycosaminoglycans.

Similarly to the lining cells of the male atrium, the lining cells of the female atrium also show cytoplasm filled with a cyanophil secretion which stains slightly positively to $\mathrm{AB}$, indicating glycosaminoglycans. In addition, the lining epithelium of the female atrium shows an erythrophil secretion which accumulates apically.
Ejaculate (Figs. 13-14). An ejaculate was observed in three specimens of Ch.iheringi. It comprises sperm together with erythrophil, xanthophil, and/or mixed secretions. Each specimen presents the ejaculate in a different position. In one specimen, the ejaculate was attached to the lining epithelium of the ventral wall of the male atrium (Fig. 13), near the gonopore. Where the ejaculate was attached, the lining epithelium was completely destroyed, so that a layer of xanthophil secretion gathered directly onto the subjacent mesenchyme. Free sperm was observed in the proximal region of the male atrium. In a second specimen, the ejaculate, which appeared to be incompletely formed, constituted of only xanthophil and mixed secretions and sperm, was located free in the lumen of the proximal part of the male atrium. There were no alterations on the lining epithelium of the male atrium. Some free sperm was also observed in the lumen of the male atrium. In a third specimen, the ejaculate was attached to the lining epithelium of the proximal region of the female atrium (Fig. 14). In the place of attachment, the lining epithelium was completely damaged. Some free sperm was observed in the lumen of the female atrium near the vagina. In the latter specimen, stained with AZAN, it was observed that the ejaculate is constituted of erythrophil secretion (probably from type pv3 cells) forming a dense mass with clumps of xanthophil granules (probably from type pv1 and/or pv2 cells) as wells as clumps of mixed secretion (from type pv4 cells).

\section{DISCUSSION}

In the secretions of $C h$. iheringi, we observed that xanthophil substances as well as erythrophil/ xanthophil substances include basic proteins or glycoproteins. Also a mixed type of secretion containing a cyanophil marginal zone and a xanthophil/ erythrophil central core was characterized histochemically as glycoprotein. Cyanophil substances include glycosaminoglycans.

\section{Epidermis}

According to Winsor (1998), secretions from the terricolan epidermis can be classified into four types, in addition to rhabdoids, these being recognized on the basis of secretion morphology, polychrome staining reactions, and histochemistry. 
For Artioposthia triangulata (= Arthurdendyus triangulatus), McGee et al. (1996, 1997) described, in addition to rhabdoids, four types of secretions, with two of them produced by insunk cell bodies and recognized by light microscopy, another one produced by epidermal cells, and a fourth one presenting an uncertain origin.

For Ch. iheringi, besides the rhabditogen glands (types e3 and e4), two secretory cell types were identified in the epidermis at the level of the pre-pharyngeal region. There is no marginal adhesive zone, as Froehlich (1955) already verified for several Choeradoplana species.

Cyanophil (basiphil) glands, as type e1 cells of Ch. iheringi, were already recognized as mucous glands by Graff (1899), who observed numerous cyanophil glands opening through the ventral epidermis of Terricola. Winsor (1998) noted the role of the mucus, provided by the cyanophil epidermal glands, upon which the flatworm glides, using the cilia of the creeping sole. The distribution of the epidermal cyanophil secretory cells of $C h$. iheringi (type el cells) is similar to the description of Graff (1899) and Hyman (1951) for land planarians in general. According to Froehlich (1955), the distribution of the cyanophil cells varies in different species of Choeradoplana, so that in Ch. iheringi and $C h$. langi these cells are more numerous at the creeping sole, whereas in the same place in $C h$. marthae and Ch. catua the cyanophil cells are scarce. Winsor (1998) commented on the occurrence of two types of secretion for terricolan cyanophil glands, one containing glycogen, and the other secreting acidic mucopolysaccharide. In the epidermis of $C h$. iheringi, we could recognize cyanophil secretory cells containing the latter-mentioned type of secretion, whereas glycogen was detected in the basal cytoplasm of the epidermal lining cells. In Bipalium kewense (Hauser, 1966) and B. adventitium (Curtis et al., 1983), however, glycogen was detected in insunk secretory cells, protecting these cells from mechanical stress, and facilitating a greater accumulation of glycogen. This insunk condition for glycogen accumulation was not observed in Ch. iheringi.

TABLE 1

Mean size and standard deviation $(\mathrm{mm})$ of the secretory granules and staining properties of the secretion in the various secretory cell types opening through the epidermis of $\mathrm{Ch}$. iheringi. -: negative reaction; +: weakly positive reaction: ++: moderately positive reaction; +++: strongly positive reaction; *: in Historesin; GAGs: glycosaminoglycans.

\begin{tabular}{|c|c|c|c|c|c|c|c|c|c|c|c|}
\hline & $\begin{array}{l}\text { Mean size and } \\
\text { standard } \\
\text { deviation } \\
(\mu \mathrm{m})\end{array}$ & AZAN & Cason & Masson & $\begin{array}{l}\text { Toluidine } \\
\text { Blue }\end{array}$ & $\begin{array}{c}\text { Bromophenol } \\
\text { blue }\end{array}$ & AB/PAS & DMAB & Ninhydrin & $\begin{array}{c}\text { Trichrome } \\
\text { staining } \\
\text { reaction }\end{array}$ & $\begin{array}{l}\text { Nature of } \\
\text { secretion }\end{array}$ \\
\hline e1 & $0.5^{*}$ & light blue & light blue & $\begin{array}{l}\text { light } \\
\text { green }\end{array}$ & Pink & - & $++\mathrm{AB}$ & - & - & cyanophil & GAGs \\
\hline e2 & $1 \pm 0.2$ & orange & orange & orange & Blue & + & - & - & - & xanthophil & $\begin{array}{l}\text { basic } \\
\text { protein }\end{array}$ \\
\hline e3 & $\begin{array}{c}27.0 \pm 2.0 \\
\mathrm{x} \\
1.7 \pm 0.2\end{array}$ & red & $\begin{array}{l}\text { reddish } \\
\text { orange }\end{array}$ & orange & chromophobe & +++ & - & - & - & $\begin{array}{c}\text { erythrophil/ } \\
\text { xanthophil }\end{array}$ & $\begin{array}{l}\text { basic } \\
\text { protein }\end{array}$ \\
\hline e4 & $\begin{array}{c}10.0 \pm 1.0 \\
x \\
2.0 \pm 0.5\end{array}$ & red & $\begin{array}{l}\text { reddish } \\
\text { orange }\end{array}$ & orange & chromophobe & +++ & - & - & - & $\begin{array}{l}\text { erythrophil/ } \\
\text { xanthophil }\end{array}$ & $\begin{array}{l}\text { basic } \\
\text { protein }\end{array}$ \\
\hline
\end{tabular}

TABLE 2

Mean size and standard deviation $(\mathrm{mm})$ of the secretory granules and staining properties of the secretion in the various secretory cell types opening through the pharyngeal epithelium of $\boldsymbol{C h}$. iheringi. --: amorphous secretion; -: negative reaction; +: weakly positive reaction: ++: moderately positive reaction; +++: strongly positive reaction; *: contains tryptophane; GAGs: glycosaminoglycans.

\begin{tabular}{|c|c|c|c|c|c|c|c|c|c|c|}
\hline & $\begin{array}{l}\text { Mean size and } \\
\text { standard } \\
\text { deviation }(\mu \mathrm{m})\end{array}$ & AZAN & Cason & Masson & $\begin{array}{l}\text { Bromophenol } \\
\text { Blue }\end{array}$ & AB/PAS & DMAB & Ninhydrin & $\begin{array}{c}\text { Trichrome } \\
\text { staining } \\
\text { reaction }\end{array}$ & $\begin{array}{l}\text { Nature of } \\
\text { secretion }\end{array}$ \\
\hline ph1 & $0.8 \pm 0.2$ & reddish orange & orange & orange & ++ & - & - & - & xanthophil & basic protein \\
\hline ph2 & $1.2 \pm 0.3$ & reddish orange & reddish orange & orange & +++ & +++ PAS & ++ & - & xanthophil & glycoprotein* \\
\hline ph3 & $0.7 \pm 0.2$ & orange & pink & red & - & ++ PAS & ++ & - & $\begin{array}{c}\text { erythrophil/ } \\
\text { xanthophil }\end{array}$ & glycoprotein* \\
\hline ph4 & -- & light blue & blue & light green & - & $++\mathrm{AB}$ & - & - & cyanophil & GAGs \\
\hline
\end{tabular}


TABLE 3

Mean size and standard deviation $(\mathrm{mm})$ of the secretory granules and staining properties of the secretion in the various secretory cell types opening through the lining epithelium of the male copulatory apparatus of $C h$. iheringi. --: amorphous secretion; -: negative reaction; +: weakly positive reaction: ++: moderately positive reaction; +++: strongly positive reaction; *: contains tryptophane; GAGs: glycosaminoglycans; MAC: male atrial lining cells.

\begin{tabular}{|c|c|c|c|c|c|c|c|c|c|c|c|}
\hline & & $\begin{array}{c}\text { Mean size and } \\
\text { standard } \\
\text { deviation } \\
(\mu \mathrm{m})\end{array}$ & AZAN & Cason & Masson & $\begin{array}{l}\text { Bromophenol } \\
\text { blue }\end{array}$ & AB/PAS & DMAB & Ninhydrin & $\begin{array}{l}\text { Trichrome } \\
\text { staining } \\
\text { reaction }\end{array}$ & $\begin{array}{l}\text { Nature of } \\
\text { secretion }\end{array}$ \\
\hline \multirow[t]{4}{*}{$\begin{array}{l}\text { prostatic } \\
\text { vesicle }\end{array}$} & pv1 & $1.5 \pm 0.5$ & orange & orange & orange & H & - & ++ & - & xanthophil & basic protein* \\
\hline & pv2 & $1.5 \pm 0.5$ & orange & red & orange & + & - & ++ & - & $\begin{array}{l}\text { erythrophil/ } \\
\text { xanthophil }\end{array}$ & basic protein* \\
\hline & pv3 & $2.5 \pm 0.7$ & red & orange & red & ++ & - & - & - & $\begin{array}{l}\text { erythrophil/ } \\
\text { xanthophil }\end{array}$ & basic protein \\
\hline & pv4 & $0.8 \pm 0.3$ & $\begin{array}{l}\text { blue and } \\
\text { red }\end{array}$ & $\begin{array}{l}\text { light blue and } \\
\text { orange }\end{array}$ & $\begin{array}{l}\text { green and } \\
\text { red }\end{array}$ & - & + PAS & ++ & ++ & $\begin{array}{c}\text { mixed (cyanophil and } \\
\text { erythrophil/ } \\
\text { xanthophil) }\end{array}$ & glycoprotein* \\
\hline \multirow{3}{*}{$\begin{array}{c}\text { male } \\
\text { atrium }\end{array}$} & mal & $1.0 \pm 0.2$ & red & orange & orange & ++ & ++ PAS & +++ & $++(?)$ & $\begin{array}{l}\text { erythrophil/ } \\
\text { xanthophil }\end{array}$ & glycoprotein* \\
\hline & $\mathrm{ma} 2$ & -- & light blue & lilac & $\begin{array}{l}\text { light } \\
\text { green }\end{array}$ & - & $++\mathrm{AB}$ & - & - & cyanophil & GAGs \\
\hline & MAC & -- & blue & lilac & green & - & $++\mathrm{AB}$ & - & - & cyanophil & GAGs \\
\hline
\end{tabular}

TABLE 4

Mean size and standard deviation $(\mathrm{mm})$ of the secretory granules and staining properties of the secretion in the various secretory cell types opening through the lining epithelium of the female copulatory apparatus of $\mathrm{Ch}$. iheringi. --: amorphous secretion; -: negative reaction; +: weakly positive reaction: ++: moderately positive reaction; +++: strongly positive reaction; *: contains tryptophane; AS: apical secretion; FAC: female atrial lining cells; GAGs: glycosaminoglycans.

\begin{tabular}{|c|c|c|c|c|c|c|c|c|c|c|c|}
\hline & & $\begin{array}{l}\text { Mean size and } \\
\text { standard } \\
\text { deviation }(\mu \mathrm{m})\end{array}$ & AZAN & Cason & Masson & $\begin{array}{c}\text { Bromophenol } \\
\text { blue }\end{array}$ & AB/PAS & DMAB & Ninhydrin & $\begin{array}{c}\text { Trichrome } \\
\text { staining } \\
\text { reaction }\end{array}$ & $\begin{array}{c}\text { Nature of } \\
\text { secretion }\end{array}$ \\
\hline $\begin{array}{l}\text { shell } \\
\text { glands }\end{array}$ & sg & $1.0 \pm 0.5$ & red & orange red & orange red & +++ & +++ PAS & - & - & xanthophil & glycoprotein \\
\hline \multirow[t]{4}{*}{$\begin{array}{l}\text { female } \\
\text { atrium }\end{array}$} & $\mathrm{fa} 1$ & $0.7 \pm 0.2$ & orange & orange & red & ++ & - & - & ++ & $\begin{array}{c}\text { erythrophil/ } \\
\text { xanthophil }\end{array}$ & basic protein \\
\hline & $\mathrm{fa} 2$ & -- & $\begin{array}{l}\text { light } \\
\text { blue }\end{array}$ & lilac & light green & - & $++\mathrm{AB}$ & - & - & cyanophil & GAGs \\
\hline & FAC & -- & blue & $\begin{array}{l}\text { light } \\
\text { blue }\end{array}$ & green & - & $++\mathrm{AB}$ & - & - & cyanophil & GAGs \\
\hline & AS & $\sim 0.5$ & red & orange & orange & +++ & - & ++ & - & $\begin{array}{c}\text { erythrophil/ } \\
\text { xanthophil }\end{array}$ & basic protein* \\
\hline \multirow[t]{2}{*}{ vagina } & val & $0.7 \pm 0.2$ & orange & orange & red & ++ & - & - & ++ & $\begin{array}{r}\text { erythrophil/ } \\
\text { xanthophil }\end{array}$ & basic protein \\
\hline & va2 & -- & $\begin{array}{l}\text { light } \\
\text { blue }\end{array}$ & lilac & light green & - & $++\mathrm{AB}$ & - & - & cyanophil & GAGs \\
\hline
\end{tabular}

Graff (1899) identified, mainly in Haematoxylin/Eosin stained sections, erythrophil glands occurring abundantly in the dorsum and body margins of species of the genera Dolichoplana, Choeradoplana, Pelmatoplana, and Polycladus. Winsor (1998) refers to the even distribution of erythrophil glands dorso-laterally and ventrally to the edge of the creeping sole, often with a concentration along a marginal adhesive zone. For $C h$. iheringi, Ch. langi, and Ch. catua, Froehlich (1955) observed, also mainly in Haematoxylin/Eosin stained sections, that erythrophil secretory cells are more numerous at the creeping sole, which is in agreement with our observations for type e2 cells of $C h$. 
iheringi. Winsor (1998) broadly classified the erythrophil secretions of the Terricola into fine (type I) and coarse granules (type II), the latter being xanthophil according to polychrome methods. Type e2 cells of the epidermis of Ch. iheringi show fine xanthophil granules containing basic proteins. As attested by Winsor (1998), xanthophil glands have an adhesive function.
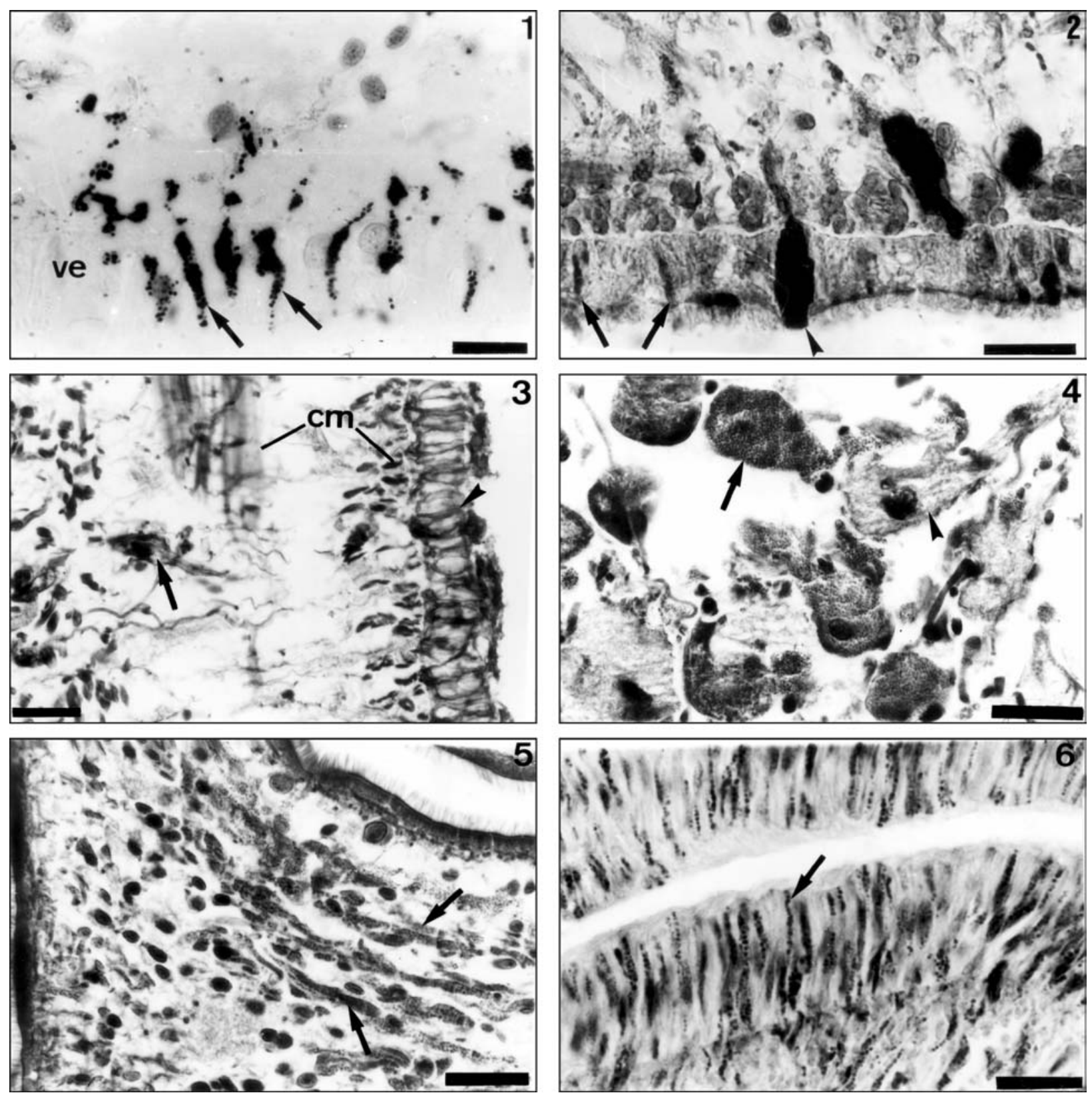

Fig. 1 - Ventral epidermis (ve) of Choeradoplana iheringi. Transverse section stained with toluidine blue. Scale bar, $20 \mu \mathrm{m}$. Arrows indicate cell necks of type e1 secretory cells. Fig. 2 - Ventral epidermis of Choeradoplana iheringi. Sagittal section stained with Heidenhain's AZAN. Scale bar, $20 \mu \mathrm{m}$. Note the cell necks of types e2 (arrows) and e4 secretory cells (arrow head). Fig. 3 - Dorsal epidermis of Choeradoplana iheringi. Sagittal section stained with bromophenol blue. Scale bar, $30 \mu \mathrm{m}$. Note positive reaction of rhabidtes of type e3 secretory cells in the cell body (arrow) and cell necks throughout the dorsal epidermis (arrow head). cm: cutaneous muscles. Fig. 4 - Cell bodies of pharyngeal glands in the pre-pharyngeal region of Choeradoplana iheringi. Transverse section stained with Goldner's Masson. Scale bar, $30 \mu \mathrm{m}$. Arrow indicates cell body of type ph1; arrow head indicates cell body of type ph4 secretory cells. Fig. 5 - Pharynx of Choeradoplana iheringi. Sagittal section stained with Goldner's Masson. Scale bar, $20 \mu \mathrm{m}$. Arrows indicate cell necks of the pharyngeal glands. Fig. 6 - Proximal portion of the prostatic vesicle of Choeradoplana iheringi. Sagittal section stained with Goldner's Masson. Scale bar, $20 \mu \mathrm{m}$. Arrow indicates a cell neck of type pv1 secretory cells. 

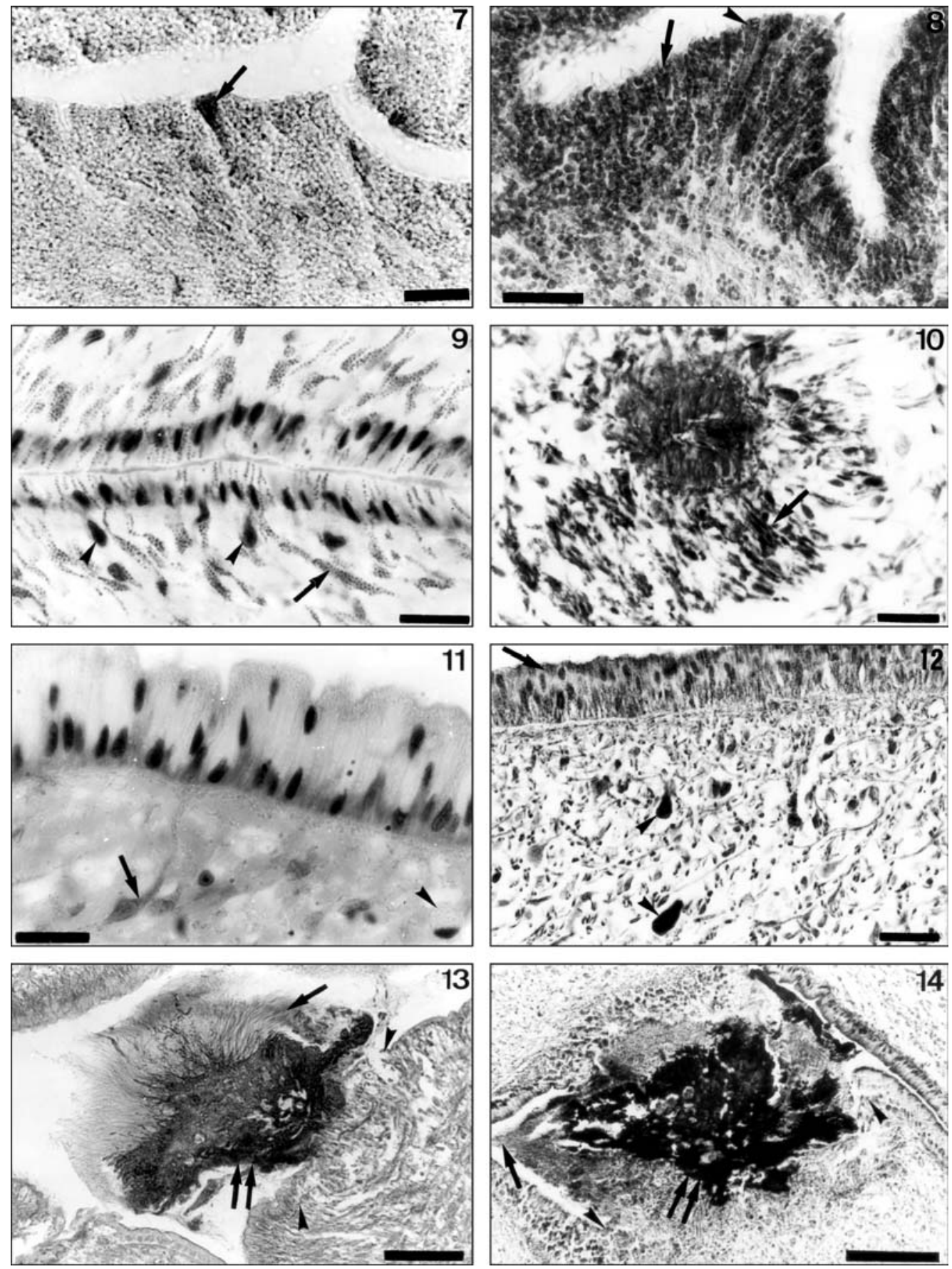

Fig. 7 - Distal portion of the prostatic vesicle of Choeradoplana iheringi. Sagittal section stained with DMAB. Scale bar, $20 \mu \mathrm{m}$. Arrow indicates positive reaction of type pv2 secretory cells. Fig. 8 - Distal portion of the prostatic vesicle of Choeradoplana iheringi. Horizontal section stained with Heidenhain's AZAN. Scale bar, $30 \mu \mathrm{m}$. Arrow indicates a cell neck of type pv3 secretory cells, the most frequent ones; arrowhead indicates a cell neck of type pv4 secretory cells. Fig. 9-Male atrium of Choeradoplana iheringi. Sagittal section stained with toluidine blue. Scale bar, $20 \mu \mathrm{m}$. Arrow indicates a cell neck of type mal secretory cells; arrowheads indicate cell bodies of type ma2 secretory cells. Fig. 10 - Common glandular duct of Choeradoplana iheringi. Sagittal section stained with bromophenol blue. Scale bar, $20 \mu \mathrm{m}$. Arrow indicates positive reaction in a cell neck of the shell glands. Fig. 11 - Female atrium of Choeradoplana iheringi. Sagittal section stained with toluidine blue. Scale bar, $20 \mu \mathrm{m}$. Arrow indicates a cell body and cell neck of type fa1 secretory cells; arrowhead indicates a cell body of type fa2 secretory cells. Fig. $12-\mathrm{Fe}-$ male atrium of Choeradoplana iheringi. Sagittal section stained with Heidenhain's AZAN. Scale bar, $20 \mu \mathrm{m}$. Arrow indicates secretion accumulated in the apical cytoplasm of the lining epithelium; arrowheads indicate cell bodies of type fa1 secretory cells. Fig. 13 - Ejaculate in the male atrium of Choeradoplana iheringi. Sagittal section stained with Cason's Mallory. Scale bar, $100 \mu \mathrm{m}$. Arrow indicates sperm; double arrow indicates xanthophil secretion; arrowheads indicate damaged epithelium. Fig. 14 - Ejaculate in the female atrium of Choeradoplana iheringi. Horizontal section stained with Heidenhain's AZAN. Scale bar, $100 \mu \mathrm{m}$. Arrow indicates sperm; double arrow indicates erythrophil secretion; arrowheads indicate damaged epithelium. 
Froehlich (1955) mentioned, for Ch. iheringi and various other geoplaninids, the occurrence of special non-ciliated epidermal cells at the margins of the body, these receiving the ducts of subepidermal glands, similar to the adhesive marginal glands of marine and freshwater triclads. Such cells could not be detected in the material of Ch. iheringi analyzed in the present work.

Rhabdoids, i.e. rod-like secretions, can be produced in the epidermis (dermal rhabdites) or by rhabditogen cells lying in the mesenchyme (adenal rhabdites) (Hyman, 1951), the adenal type being true rhabdites, whereas the dermal ones are better denominated as epitheliosomes (Smith et al., 1982; Tyler, 1984). McGee et al. (1996) differentiated these two types of rhabdoids for A. triangulatus at the ultrastructural level, characterizing their mechanism of formation, transport, and release. Winsor (1998) commented that the commonest rhabdoid type in the terricolan epidermis are the rhammites, i.e., sinuous rhabdoids longer than the height of the epithelium, which are distributed dorsolaterally, extending ventrally to the margins of the creeping sole. Rhabdoids are strongly acidophil and contain proteins with a disulphide component (Curtis et al., 1983), and also uroporphyrins (Winsor, 1990). According to Rieger et al. (1991) and Winsor (1998), the functions of rhabdoids are uncertain since it is difficult to isolate their effects from those of other secretion types with a parallel distribution. In Ch. iheringi, as in other geoplaninids, the abundant dorsolateral rhabdoids of type e 3 cells are rhammites, which are so long that they can often be observed rolled up in spiral form. The rhabdoids of type e 4 cells, occurring through the creeping sole, also of the adenal type, are, however, much shorter. Both dorsolateral and ventral rhabdoids of $C h$. iheringi show similar reactions to trichrome and histochemical methods, being both xanthophil and positive for basic proteins.

The secretions produced by the epidermis of land flatworms have to do with adhesive, locomotory, prey capture, repugnatorial, and homeostatic functions (Hyman, 1951; Winsor, 1998). The mucus of the flatworm A. triangulatus has been characterized as slightly acidic with hydrolytic enzymes which may play a role both in prey digestion and in softening the body cuticle of its prey (McGee et al., 1998).

\section{Pharynx}

According to Hyman (1951), the pharyngeal glands play a role in prey immobilization as well as assisting in lubrication of the ingestion process. As indicated by Jennings (1974), the pharyngeal secretions of triclads contribute significantly to the disruption of the prey's body contents before these are sucked through the pharynx into the intestine. Erythrophil and cyanophil glands were reported for Ch. marthae and Ch. langi, respectively, by Froehlich (1955) and Du Bois-Reymond Marcus (1951). Froehlich (1955) observed cyanophil cells in $C h$. marthae opening on all the pharyngeal surface and erythrophil ones on the folded margins, whereas $\mathrm{Du}$ Bois-Reymond Marcus (1951) reported the openings of cyanophil glands on the outer pharyngeal surface, and those of erythrophil glands on the margins and through the wall of the pharyngeal pouch. Winsor (1990) described the cyanophil glands in Platydemus manokwari as being concentrated ectally, opening through the outer epithelium, whereas the erythrophil secretions (Winsor, pers. comm.) predominate in the mid region, opening into the internal pharyngeal surface and through the pharyngeal lip. As a result of a combination of trichrome and histochemical methods, four types of secretory cells were observed in the pharynx of Ch. iheringi, the openings of which occur on all the internal and external pharyngeal surface. Jennings (1974) reported that in triclads a large number of acidophil secretions of the pharyngeal glands, opening into the outer surface of the pharynx, contains endopeptidases involved in the disruption of the prey's body contents.

\section{Copulatory organs}

Graff (1899), Marcus (1951), and Froehlich (1955) describe the occurrence of abundant erythrophil secretions opening through the epithelium of the seminal vesicle (= prostatic vesicle) in species of Choeradoplana. In Ch. iheringi, the region which has been termed the seminal vesicle by Graff (1899) and Marcus (1951) corresponds to the here-named distal portion of the prostatic vesicle (Leal-Zanchet \& Souza, 2003).

The histology of the copulatory apparatus of geoplaninid species is mainly known from Haematoxylin/Eosin stained sections used for taxonomic studies, where only cyanophily and eosinophily can be detected. Winsor (1991a, 1998) has emphasized the use of other staining techniques. According to Winsor (1990), Platydemus manokwari shows a long seminal vesicle with proteic secretions containing disulphide groups and a differentiated prostatic region, the secretions of which contain acid phos- 
phatases, tryptophane, and lipids. In Ch. iheringi, both parts of the prostatic vesicle show cell types with basic protein (with and without tryptophane), the distal portion also presenting an additional type with glycoproteic secretion containing tryptophane. It must, however, remain open whether this organ, herein named a prostatic vesicle, really functions as a prostate, as enzyme histochemistry was not used until relatively recently to investigate the copulatory organs, either of Choeradoplana or the other geoplaninids. The former term used to designate this organ in geoplaninids, i.e. seminal vesicle, is inappropriate, as sperm have never been observed stored in this region.

No clear anatomical criteria have as yet been proposed for the differentiation of male, female, and common atria in land planarians (Winsor, 1998). This author emphasizes the use of histological criteria, such as the presence or absence of certain cell types, to define atrial functions. The atrium was defined by Cannon (1986) as the space into which both the male and female systems open before expulsion of sex products via a common gonopore. It has various functions related to copulation, resorption, and cocoon formation, as well as being able to serve as a bursa receiving and nourishing the ejaculate (Winsor, 1998). After the present preliminary histochemical study, we can differentiate the male and female atria of Ch. iheringi by a type of secretion coming from secretory cells which open through the atrial epithelium. Thus, the occurrence of glycoproteic secretion containing tryptophane (type ma1) was detected only in the male atrium whereas type fal secretory cells which open through the female atrial epithelium produce a secretion composed of basic protein. The cytoplasm of the epithelial lining cells of both male and female atria secretes glycosaminoglycans, but an erythrophil secretion accumulates in the apical third of the female atrial epithelium. Winsor (1998) suggested that acidic mucopolysaccharides (= glycosaminoglycans) may protect the epithelium from harmful intermediaries during sclerotin formation, as well as act as a lubricant or non-sticking surface.

The process of cocoon formation has been described by Winsor $(1990,1998)$ for Platydemus manokwari as presenting three main stages. Two cell types are involved (the globule cells and the strand cells) in the second stage of this process, which takes place in the female atrium. The strand cells are cyanophil insunk cells, and the globule cells show fine erythrophil globules containing an amino acidrich protein (probably derived from tryptophanecontaining granules) together with polyphenol oxidase. In the present studies on $C h$. iheringi, no cocoon formation could be observed but according to the histological and histochemical results, the apical erythrophil secretion of the female atrial epithelium, which is positive for tryptophane, may correspond to the globule cells of Platydemus manokwari.

In Ch. iheringi a penis papilla is absent. The atrial musculature, mainly the longitudinal layer which is, situated below the lining epithelium of the male atrium, is strongly developed. The common muscle coat is also well developed, mainly at the level of the male atrium (Leal-Zanchet \& Souza, 2003). We can only speculate whether its male atrial wall is everted during copulation to form a temporary penis papilla, as illustrated and discussed by Hyman (1940) for Rhynchodemus atropurpureus (= Microplana atropurpurea) and by Marcus (1951) for Geoplana marginata (= Notogynaphallia marginata). To complicate the interpretation of the physiology of copulation, in three specimens of $C h$. ihering $i$ we observed the presence of an ejaculate in the atria, in two of which this was attached to the atrial wall through degradation of the epithelium.

An ejaculate has also been reported for Geoplana sextriata (= Notogynaphallia sextriata) (Froehlich, 1956), G. mülleri (= Notogynaphallia mülleri) (Froehlich, 1959), G. righii (= Amaga righii) (Froehlich \& Froehlich, 1972), Pimea monticola (Winsor, 1991b), and Platydemus victoriae (Heinzel in Winsor, 1998). In the two above mentioned species of Notogynaphallia studied by Froehlich $(1956,1959)$, the ejaculate is represented by a cluster of sperm, perpendicularly oriented to the epithelial surface of the atrium, and attached through a mass of erythrophil secretion to the atrial surface. Froehlich (1959) also observed damage of the atrial epithelium at the place of attachment, as well as eosinophil secretion partially covering the whole cluster of sperm. The morphology and situation of the ejaculate described by Froehlich $(1956,1959)$ are very similar to our observations in the two specimens of $C h$. iheringi with the ejaculate attached to the atrial wall.

The reactions of the erythrophil, xanthophil, and mixed secretions of the ejaculate of Ch. iheringi to trichrome methods indicate that they are derived from the prostatic vesicle. Also in a specimen of Ch. iheringi, in which the ejaculate is observed to 
be free in the proximal part of the male atrium, near the prostatic vesicle, abundant secretions are associated with the sperm.

In the four geoplaninid species, in which an ejaculate has been observed attached to the atrial wall, a penis papilla is absent. In N. sexstriata, $N$. mülleri, and $A$. righii, as well as in one specimen of $C h$. iheringi, the ejaculate was attached to a ventral fold of the male atrium, near the gonopore. The absence of a penis papilla led Froehlich (1956) to propose that this ventral fold would substitute for a penis papilla, introducing the associated sperm, as spermatophores, into the female atrium of a partner during copulation. We are of the opinion that this is also the most likely explanation for sperm transfer in Ch. iheringi. There are two other specimens of $C h$. iheringi in which the ejaculate is in a different position: in one of them, it is probable that when it is free in the proximal portion of the male atrium the ejaculate is still being formed; in the other specimen, the ejaculate has proceeded from a partner after copulation, becoming attached to the female atrial wall with free sperm being near the vagina. The secretions of the female atrium may possibly act in setting sperm free to penetrate the vagina.

The occurrence of spermatophores is rare in Terricola (Winsor, 1998). A true spermatophore has been described by Winsor (1991b) for Pimea monticola, occurring inside the copulatory bursa, and consisting of an inner core of sperm mixed with acidophil secretion, and surrounded by layers of acidophil and cyanophil secretions. The ejaculate described for A. righii, Ch. iheringi, N. sexstriata, and $N$. mülleri differs from the spermatophore of P. monticola in the sperm which have not been completely surrounded by secretions. It may, however, function as a spermatophore, playing perhaps an important role in sperm transfer during copulation for species without a penis papilla.

According to Winsor (1998), the ejaculate of Platydemus manokwari is similar to those reported from mammalian ejaculates, being composed of sperm surrounded by disulphide proteins derived from the seminal vesicle, and mixed with proximal prostatic secretions consisting of tyrosine, lipids, and a secretory acid phophatase, together with basic proteins of the distal prostatic region. It acts in sperm delivery and protection in the viscid seminal secretions as well as dissolution of the ejaculate by prostatic secretions.
Acknowledgements - We are grateful to Mr. Leigh Winsor for his constructive comments and suggestions on an early draft of the manuscript; to Prof. Dr. Eudóxia Froehlich for welcome professional dialogue about the taxonomy and reproduction of geoplanids; to the colleagues from the Instituto de Pesquisas de Planárias for their help in collecting specimens; to the laboratorial technicians J. C. Rodrigues and L. A. Guterres for assistance with preparation of sections as well as to T.H. Oliveira for photographic work. Thanks are also due to R. A. Clark, and E. Benya for his help with the English version of this text.

\section{REFERENCES}

BOIS-REYMOND MARCUS, E., 1951, On South American Geoplanids. Bol. Fac. Fil. Ciênc. Letr. Univ. São Paulo, Sér. Zoologia, 16: 217-256.

CANNON, L. G. R., 1986, Tubellaria of the world. A guide to families and genera. Queensland Museum, Brisbane, 136p.

CARBAYO, F. \& LEAL-ZANCHET, A. M., 2001, A new species of terrestrial planarian (Platyhelminthes, Tricladida, Terricola) from South Brazil. Rev. Brasil. Biol., 61(3): 437-447.

CURTIS, S. K., COWDEN, R. R., MOORE, J. D. \& ROBERTSON, J. L., 1983, Histochemical and ultrastructural features of the epidermis of the land planarian Bipalium adventilium. J. Morphol., 175: 171-194.

FROEHLICH, C. G., 1955, Sobre morfologia e taxonomia das Geoplanidae. Bol. Fac. Fil. Ciênc. Letr. Univ. São Paulo, Sér. Zoologia, 19(16): 289-369.

FROEHLICH, C. G., 1956, Tricladida Terricola das regiões de Teresópolis e Ubatuba. Pap. Av. Depto. Zool., 12: 313-344.

FROEHLICH, C. G., 1959, On Geoplanids from Brazil. Bol. Fac. Fil. Ciênc. Letr. Univ. São Paulo, Sér. Zoologia, 22: 201242.

FROEHLICH, E. M., 1955, Sobre espécies brasileiras do gênero Geoplana. Bol. Fac. Fil. Ciênc. Letr. Univ. São Paulo, Sér. Zoologia, 19: 289-369.

FROEHLICH, E. M., 1978, On a collection of Chilean land planarians. Bol. Fac. Fil. Ciênc. Letr. Univ. São Paulo, Sér. Zoologia, 3: 7-80.

FROEHLICH, E. M. \& FROEHLICH, C. G., 1972, Land planarians from the Amazonian region. Papéis Avulsos Depto. Zool., 26(2): 29-45.

GRAFF, L. von, 1899, Monographie der Turbellarien. Vol. 2. Tricladida, Terricola (Landplanarien). Engelmann, Leipzig, $574 \mathrm{p}$.

HAUSER, J., 1952, Ausschaltung des Xylols in der histologischen Technik. Mikroskopie, 7(5-6): 208-209.

HAUSER, J., 1966, Beiträge zur Turbellarienhistologie. Die histologische Struktur der Kriechsohle von Bipalium kewense. Pesq. Zool., 19: 1-23.

HYMAN, L. H., 1940, Land planarians from the Palau and Caroline Islands, Micronesia. Ann. \& Mag. N. Hist., Ser. 11, 5: 346362.

HYMAN, L. H., 1951, The invertebrates. Platyhelminthes and Rhynchocoela. McGraw-Hill, New York, vol. II, 550p. 
JENNINGS, J. B., 1974, Digestive physiology of the Turbellaria, pp. 173-197. In: N. W. Riser \& M. P. Morse (eds.), Biology of the Turbellaria. McGraw-Hill, New York, 530p.

LEAL-ZANCHET, A. M. \& CARBAYO, F., 2001, Two new species of Geoplanidae (Platyhelminthes, Tricladida, Terricola) from Brazil. J. Zool., 253: 433-446.

LEAL-ZANCHET, A. M. \& SOUZA, S. A., 2003, Redescrição de Choeradoplana iheringi Graff (Platyhelminthes, Tricladida, Terricola). Rev. Bras. Zool., 20(3): 523-530.

MARCUS, E., 1951, Turbellaria brasileiros (9). Bol. Fac. Fil. Ciênc. Letr. Univ. São Paulo, Sér. Zoologia, 16: 5-215.

MCGEE, C., FAIRWEATHER, I. \& BLACKSHAW, R. P., 1996, Ultrastructural observations on rhabdite formation in the planarian, Artioposthia triangulata. J. Zool., 240: 563-572.

MCGEE, C., FAIRWEATHER, I. \& BLACKSHAW, R. P., 1997, Ultrastructural features of the epidermis of the planarian, Artioposthia triangulata (Dendy). Hydrobiologia, 347: 1524.

MCGEE, C., WISDOM, G. B., FAIRWEATHER, I., BLACKSHAW, R. P., MCILROY, J. \& WALKER, B., 1998, Characterization of the proteins present in the mucus of the flatworm Artioposthia triangulata (Dendy). Comp. Biochem. Physiol., 119B(2): 293-298.

PEARSE, A. G. E., 1968, Histochemistry theoretical and applied. J. \& A. Churchill Ltd., London, vol. 1, 756p.

PLATTNERT, N., 1975, Die chemische Fixierung biologische Objekte für die Eletronenmikroskopie, pp. 39-40. In: G. Schimmel \& W. Vogell (eds.), Methodensammlung der Elektronenmikroskopie. Wissenschaftliche Verlagsgesellschaft $\mathrm{mbH}$, Stuttgart.

RIEGER, R. M., TYLER, S., SMITH III, J. P. S. \& RIEGER, G., 1991, Platyhelminthes: Turbellaria, pp. 47-68. In: F. W. Harrison \& B. J. Bogitsh (eds.), Microscopic anatomy of invertebrates. vol. 3. Platyhelminthes and Nemertinea. WileyLiss, New York, 347p.
ROMEIS, B., 1989, Mikroskopische Technik. Urban und Schwarzenberg, München, 697p.

RUTHMANN, A., 1966, Methoden der Zellforschung. Franckh'sche Verlagshandlung, Stuttgart, 301p.

SMITH, J. III, TYLER, S., THOMAS, M. B. \& RIEGER, R. M., 1982., The morphology of Turbellarian rhabdites: phylogenetic implications. Trans. Am. Microsc. Soc., 101(3): 209-228.

SPURLOCK, B. O., SKINNER, M. S. \& KATTINE, A. A., 1966, Simple rapid method for staining epoxi-embedded specimens for light microscopy with the polichromatic staining Paragon 1031. Am. J. Clin. Pathol., 46: 252-258.

TYLER, S., 1984, Turbellarian Platyhelminths, pp. 112-131. In: J. Bereiter-Hahn, A. G. Matoltsy \& K. S. Richards (eds.), Biology of the Integument, vol. I. Invertebrates. SpringerVerlag, Berlin, 841p.

WINSOR, L., 1990, Taxonomic studies on free-living flatworms (Turbellaria: Platyhelminthes) of the Australasian zoogeographic region. Master of Science Thesis, Faculty of Science, James Cook University of North Queensland, 175p.

WINSOR, L., 1991a, Methods for taxonomical and distributional studies of terrestrial flatworms (Tricladida: Terricola). Hydrobiologia, 227: 349-352.

WINSOR, L., 1991b, A new genus and species of terrestrial flatworm from the central highlands of New Caledonia (Tricladida: Terricola). Mém. Mus. Natn. Hist. Nat., Serie A, 149: 19-30

WINSOR, L., 1998, Aspects of taxonomy and functional histology in terrestrial flatworms (Tricladida: Terricola). Pedobiologia, 42: 412-432. 